\title{
Albatrellopsis flettii, A New Genus for Turkish Albatrellaceae
}

\author{
Deniz ALTUNTAŞ ${ }^{1}$, Ergin ŞAHİN 2 , Şanlı KABAKTPE ${ }^{3}$, Hakan ALLI $^{4}$, Ilgaz AKATA ${ }^{\circ}$ \\ ${ }^{1}$ AnkaraUniversity Graduate School of Natural and Applied Sciences, Ankara, Turkey, ${ }^{2,5}$ Ankara University, Faculty of Science, Department \\ of Biology, Ankara, Turkey, ${ }^{3}$ Malatya Turgut Ozal University, Battalgazi Vocat Sch., Battalgazi, Malatya, Turkey, ${ }^{4}$ Muğla Sıtkı Koçman \\ University, Faculty of Science, Department of Biology, Muğla,Turkey \\ ${ }^{1}$ https://orcid.org/0000-0003-0142-6188, ${ }^{2}$ https://orcid.org/0000-0003-1711-738X, ${ }^{3}$ https://orcid.org/0000-0001-8286-9225 \\ ${ }^{4} \mathrm{https}: / /$ orcid.org/0000-0001-8781-7089, ${ }^{2} \mathrm{https}: / /$ orcid.org/0000-0002-1731-1302 \\ $\bowtie$ : akata@science.ankara.edu.tr
}

\section{ABSTRACT}

Fungal samples were collected from Kazdağ (Balıkesir/Turkey) on October 25, 2014, and they were identified by implementing both traditional methods and ITS rDNA-based molecular phylogenetic analysis. By taking into account the high sequence similarity between the collected samples (ANK DNZ 023) and Albatrellopsis flettii (Morse ex Pouzar) Audet, the collected specimen was regarded as $A$. flettii, which was also verified my the morphological data. As a result, $A$. flettii was reported for the first time from Turkey at the genus and species level. A short description of the newly reported species was provided together with its macrophotography, illustrations of spores and hyphae, and spore images taken by a scanning electron microscope (SEM).

\section{Albatrellopsis flettii, Türkiye Albatrellaceae'leri İçin Yeni Bir Cins}

\section{ÖZET}

Mantar örnekleri 25 Ekim 2014 tarihinde Kazdağı Milli Parkı'ndan (Balıkesir / Türkiye) toplandı ve hem geleneksel yöntemler hem de ITS rDNA tabanlı moleküler filogenetik analiz uygulanarak tanımlandı. Toplanan örnekler (ANK DNZ 023) ve Albatrellopsis flettii (Morse ex Pouzar) Audet arasındaki yüksek sekans benzerliği dikkate alınarak toplanan örnek $A$. flettii olarak kabul edildi ve morfolojik veriler de bu bulguyu pekiştirdi. Sonuç olarak, A. flettii Türkiye'den ilk kez cins ve tür seviyesinde rapor edilmiştir. Yeni rapor edilen türlerin kısa açıklaması, makro fotoğrafları, spor ve hifsel yapılarının çizimleri ve tarama elektron mikroskobu (SEM) ile alınan spor görüntüleri ile birlikte verilmiştir.

\section{Research Article}

$\begin{array}{ll}\text { Article History } & \\ \text { Received } & : 23.09 .2020 \\ \text { Accepted } & : 23.11 .2020\end{array}$

Keywords

Albatrellopsis flettii

Albatrellaceae

New record

Turkey

\section{Araștırma Makalesi}

\section{Makale Tarihçesi}

Geliş Tarihi : 23.09 .2020

Kabul Tarihi : 23.11 .2020

\section{Anahtar Kelimeler}

Albatrellopsis flettii

Albatrellaceae

Yeni kayıt

Türkiye

To Cite : Altuntaş D, Şahin E, Kabaktepe Ş, Allı H, Akata I 2021. Albatrellopsis flettii, A New Genus for Turkish Albatrellaceae. KSU J. Agric Nat 24 (4): 815-819. DOI: 10.18016/ksutarimdoga.vi.799215.

\section{INTRODUCTION}

Albatrellaceae is a family of order Russulales belonging to the division Basidiomycota (Kirk et al., 2008) and it includes sixty-three confirmed species within the nine genera (Albatrellopsis Teixeira, Albatrellus Gray, Jahnoporus Nuss, Laeticutis Audet, Leucogaster R. Hesse, Leucophlebs Harkn., Mycolevis A.H. Sm., Polyporoletus Snell and Scutiger Paulet), according to index fungorum (www.indexfungorum.org; accessed 25 July 2020.).

Albatrellopsis is a monotypic genus of the family, which includes $A$. flettii (Morse ex Pouzar) Audet, which is characterized by convex to plane and bluishgreen to variously colored pileus, incurved to lobed or wavy margin, circular or irregular, with eccentric to lateral stipe, circular to angular, apricot or salmon colored pores, thick and firm flesh, white spore print, monomitic hyphal system, elliptic to ovoid and smooth and weakly amyloid spores. Formerly classified under the genus Albatrellus, A. flettii was transferred to the newly established genus Albatrellopsis due to its distinct molecular phylogenetic status (Audet, 2010).

According to Turkish literature (Doğan et al., 2005; Sesli and Denchev, 2008), seven species within the three genera (Albatrellus confluens (Alb. \& Schwein.) Kotl. \& Pouzar, A. subrubescens (Murrill) Pouzar, Laeticutis cristata (Schaeff.) Audet, Leucogaster liosporus R. Hesse, L. luteomaculatus Zeller \& C.W. Dodge, L. nudus (Hazsl.) Hollós, Scutiger pescaprae (Pers.) Bondartsev \& Singer) have so far been reported for Turkish Albatrellaceae but there is not any record related to Albatrellopsis flettii in Turkey. The purpose of this paper was to make some contributions to Turkish Albatrellaceae. 


\section{MATERIAL and METHOD}

Albatrellopsis specimens were collected from Kazdağ National Park (Balıkesir-Turkey) on October 25, 2014. Macroscopic and ecological characteristics of the specimens were recorded at the collection site. In the fungarium, microscopic structures were scrutinized using both simple light microscope and scanning electron microscope (SEM). For light microscopy, approximately 50 measurements were taken under a light microscope (Euromex Oxion Trinocular microscope). 100X magnification rates were utilized for each microscopic structure and the compiled data were statistically processed. We also benefited from some chemicals including Melzer's reagent, $5 \% \mathrm{KOH}$, and congo red. For SEM analysis, pieces of hymenium were buried in a carbon paste, coated with gold particles, and visualized with an EVO 40XVP (LEO Ltd., Cambridge, UK) scanning electron microscope by using an accelerating voltage of $15 \mathrm{kV}$. Herbarium materials were prepared from the identified samples (ANK DNZ 023) and deposited into Ankara University Herbarium (ANK).

\section{Determination of the ITS rDNA Sequences}

For the genomic DNA extraction from ANK DNZ 023, the CTAB method was employed as previously described (Rogers and Bendich, 1994). The extracted genomic DNA was spectrophotometrically (Nanodrop Lite Theromo Scientific) analyzed for the quality and quantity measurements and then it was utilized in a polymerase chain reaction as the template in order to amplify the Internal Transcribed Spacer (ITS) rDNA regions. PCR amplification of the ITS rDNA regions was implemented by using the ITS1 forward and ITS4 reverse universal oligonucleotides as previously represented (Stielow et al, 2015). The presence of amplicons was electrophoretically confirmed as single and clear bands on an agarose gel and later they were purified with Expin Gel, PCR, and CleanUp SV Kit (GeneAll) and sequenced with Sanger dideoxy sequencing method. Same ITS1 and ITS4 oligonucleotides were employed for the sequencing PCR conducted using the BigDye ${ }^{\mathrm{TM}}$ Direct Cycle Sequencing Kit (Thermo Fisher Scientific) and the fragment analyses were carried out using ABI Prism 3130 Genetic Analyzer. Agarose gel electrophoresis and the Sanger sequencing were performed as described elsewhere (Chen et al., 2014).

\section{Molecular Phylogeny Study}

For the molecular phylogeny, the sanger reads obtained from ITS1 and ITS4 primers were assembled using DNAMAN Version 10 sequence assembly software (Lynnon Corporation) and BLASTn search was implemented with the assembled sequence for the similarity index analysis. Based on this BLAST search, the in-group and the out-group members were retrieved from NCBI GenBank for the phylogenetic analysis. The assembled sequence and the nucleotide sequences of the retrieved in-group and out-group members were aligned using the ClustalW algorithm of MEGAX software (Kumar et al., 2018). The phylogenetic tree demonstrating the evolutionary history of ANK DNZ 023 was inferred using the Maximum Likelihood method and K2 nucleotide substitution model with gamma distribution (Kimura, 1980). The bootstrap method was utilized for the accuracy estimation using 1000 bootstrap replicates (Felsenstein, 1985).

\section{RESULTS}

Albatrellaceae Nuss

Albatrellopsis Teixeira

A. flettii (Morse ex Pouzar) Audet (2010), (Figure 1).

Syn.: Albatrellus flettii Morse ex Pouzar (1972), Polypilus flettii (Morse ex Pouzar) Teixeira (1992), Polyporus flettii Morse, Mycologia (1941).

\section{Macroscopic and microscopic features}

Pileus 120-160 mm broad, convex and inrolled at first, then enlarged and becoming plane, centrally depressed finally. Margin lobed or wavy and paler. Surface blue or blue-green at first, later dingy ochraceous, rusty stains in age, salmon to brick red when dry. Pores 1-4 per $\mathrm{mm}$, circular to angular. Pore surface white at first, becoming apricot or salmon when mature, brick red when dry. Flesh white, thick, and firm. Odor and taste not distinctive. Stipe 50-100 $\mathrm{mm}$ long, centric or eccentric, circular or irregular, smooth, solid, firm, whitish when young, salmon to brick red when mature or dry. Spore print white. Hyphal system up to $10 \mu \mathrm{m}$ broad, clamped, strongly inflated in the flesh of the cap and stem. Cystidia not seen. Basida 15-18 $\times$ 5-6 $\mu \mathrm{m}$, four spored, clavate with basal clamp. Basidiospores 3.5-4 x 2.5-3 $\mu \mathrm{m}$, ellipsoid to subglobose, smooth, hyaline, and weakly amyloid.

Distribution: North America and East Asia (Zheng and Liu, 2008).

Material examined: TURKEY-Balıkesir: Kazdağı National Park, under pine, $1470 \mathrm{~m}, 39^{\circ} 42^{\prime} \mathrm{N}-26^{\circ} 53^{\prime}$ E, 25.10.2014, ANK DNZ 023.

\section{Molecular Phylogeny of ANK DNZ 023}

The ITS rDNA sequence of ANK DNZ 023 obtained from Sanger sequencing was deposited into NCBI GenBank with the accession number of MT253103.1. In a phylogenetic analysis of ANK DNZ 023, considering the BLAST search results of the specimen`s nuclear ITS rDNA sequence, the genera Albatrellopsis, Albatrellus, Leucogaster, and 
Jahnoporus, some of the well-defined genera of the family Albatrellaceae, were selected for ingroup sequences and the nuclear ITS rDNA sequences of
Russula delica and Lactarius salmonicolor were selected for the outgroup sequences.

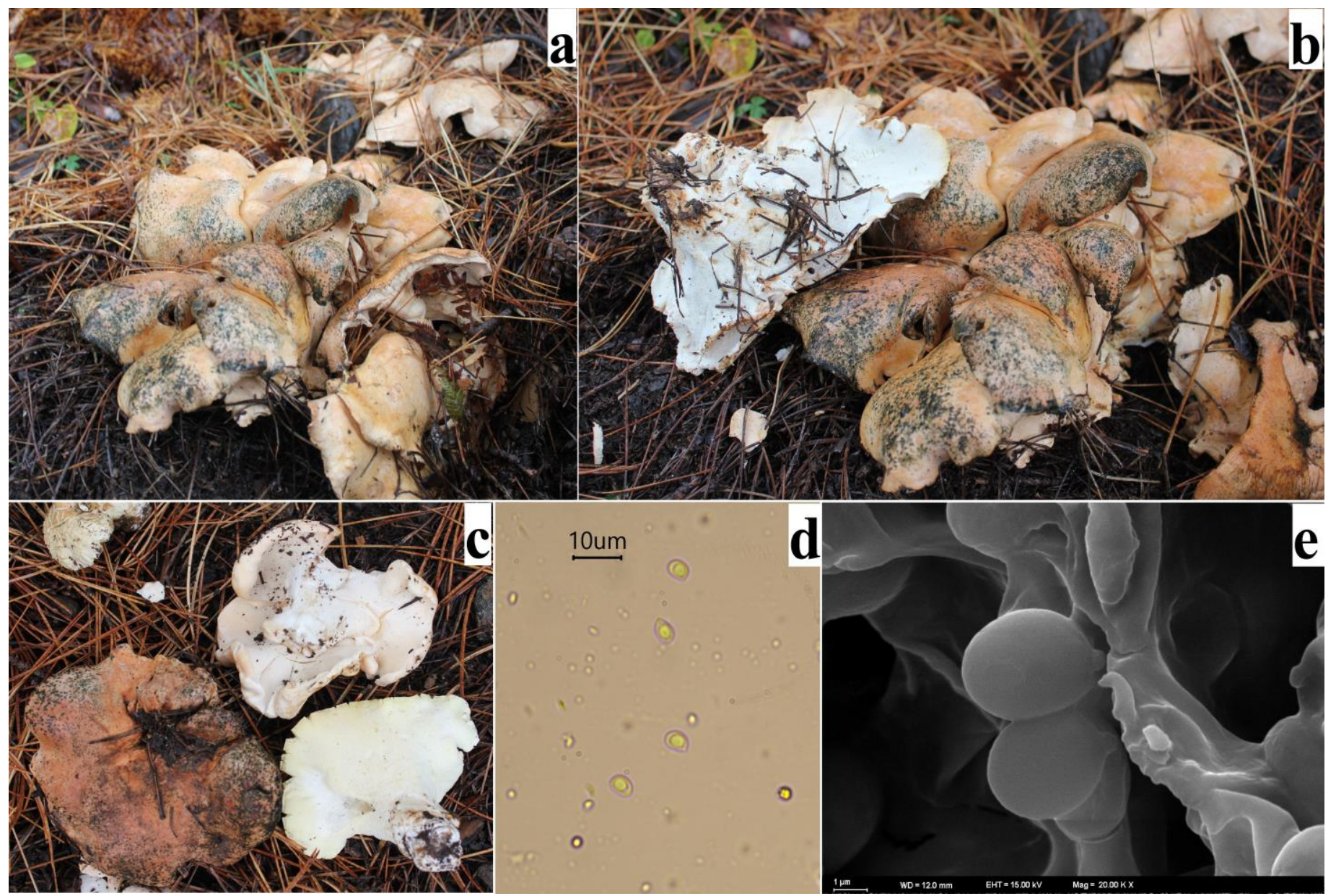

Figure 1. Albatrellopsis flettii: a-c fruit bodies, d. spores viewed under a light microscope (LM), e. spores viewed by a scanning electron microscope (SEM).

Şekil 1. Albatrellopsis flettii: a-c fruktifikasyon organları, d. sporların ışık mikroskobu (LM), altındaki görünümü, e. sporların taramalı elektron mikroskobundaki (SEM) görünümü.

As a result of the phylogenetic analysis, four apparent clades were come out along with an outgroup (Figure 2 ). While the clade 1 included different isolates of Albatrellopsis flettii and the specimen ANK DNZ 023, the Clades 2, 3, and 4 contained species from the genera Albatrellus, Leucogaster, and Jahnoporus respectively. On the other side, Russula delica and Lactarius salmonicolor fell into a distinct branch separate from the ingroup species and formed an outgroup as predicted. The BLAST analysis implemented with the nuclear ITS rDNA sequence of ANK DNZ 023 revealed identity rates as high as 99.3 $\%$ between the specimen and different isolates of $A$. flettii. The phylogenetic analyses performed herein, further strengthen the close identity relationship of this specimen with $A$. flettii with a high bootstrap value.

\section{DISCUSSION}

The distinct characteristics of $A$. flettii are bluish- green pileus developing dingy ochraceous, rusty stains in age, apricot or salmon-colored pores, clamped hyphae, small and weakly amyloid basidiospores. The species may be confused with Albatrellus confluens in terms of its morphology and ecology. Like the former species, the latter has up to $20 \mathrm{~cm}$ broad pileus, small and amyloid basidiospores and grow under conifers but the former can easily be separated from the latter by including blue tint on its pileus (Zeng et al., 2004; Zheng and Liu, 2008; Audet, 2010).

For the precise identification of fungal species, conventional methods that relied on morphological data may not be always sufficient. For this reason, conserved regions of genomic DNA including nrITS, nrSSU, and nrLSU as well as sequences of proteincoding genes are utilized for molecular taxonomic studies for the last few decades (Raja et al., 2017). Besides, ITS is the most generally used DNA barcoding marker for fungi and thus confers precious information for molecular phylogenetic studies. Therefore, we 
employed nuclear ITS rDNA sequences for the molecular identification of ANK DNZ 023. Nuclear ITS rDNA-based molecular phylogeny exhibited almost
$100 \%$ identity between $A$. flettii and the specimen (GenBank ID: MT253103.1) (Figure 2).

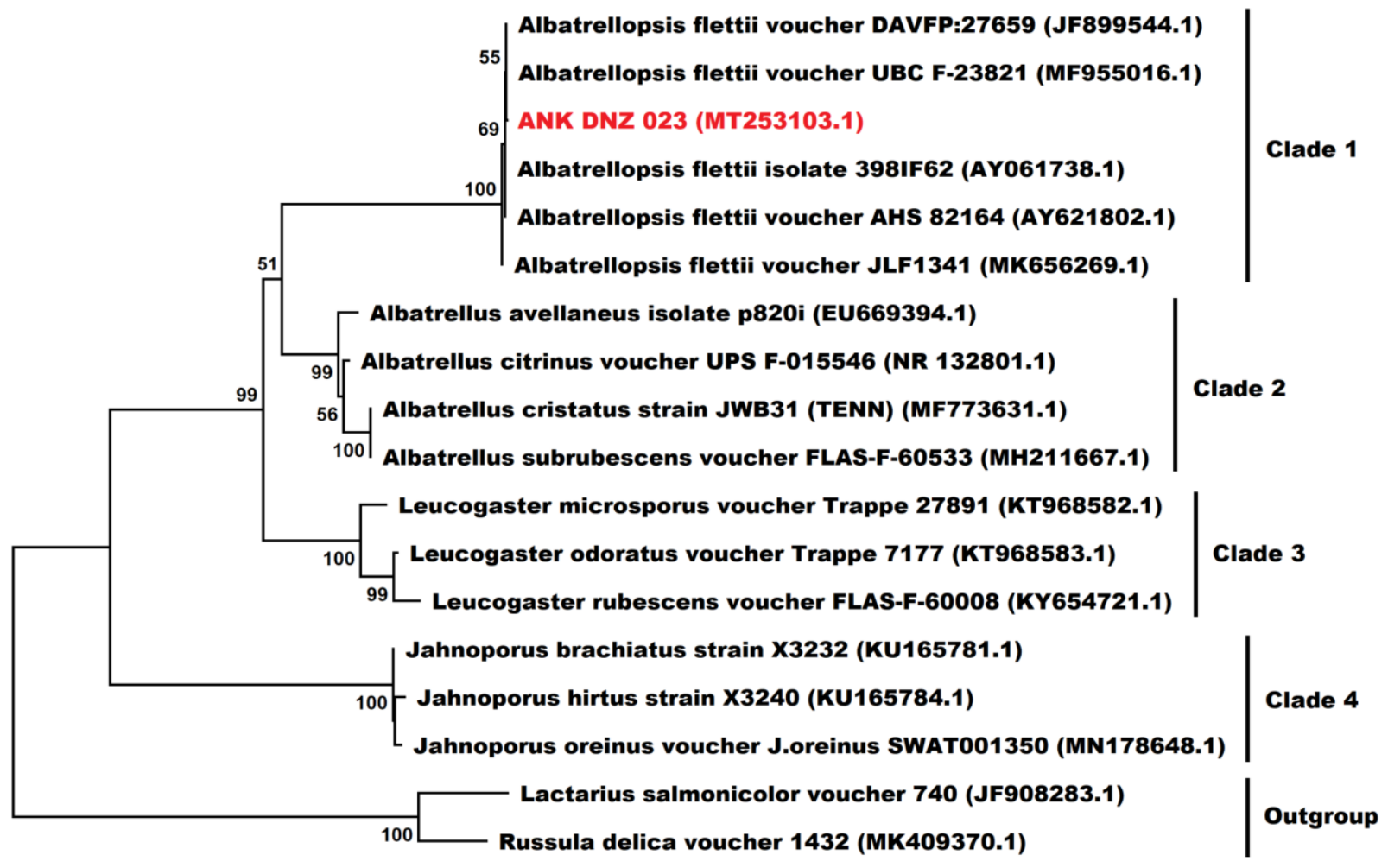

0.1

Figure 2. The Maximum Likelihood tree revealing the phylogenetic relationships of 18 fungi estimated from the nuclear ITS rDNA region. Percentage bootstrap values $(\geq 50)$ were indicated for each branch. All of the sequences included in the phylogenetic analysis were retrieved from GenBank except for ANK DNZ 023. Russula delica and Lactarius salmonicolor were included as the outgroup samples in the phylogenetic analysis. GenBank accession numbers are also given. The scale bar (lower left) represents a genetic distance of 0.11 .

Şekil 2. Cekirdek ITS rDNA bölgelerine göre tahmin edilen, 18 mantarın filogenetik ilişkilerini ortaya koyan en olası agaç. Her dal için, yüzde önyükleme değerleri ( $(50)$ belirtilmiştir. ANK DNZ 023 hariç filogenetik analize dahil edilen tüm diziler GenBank'tan alınmıştır. Russula delica ve Lactarius salmonicolor dış grup örnekleri olarak filogenetik analize dahil edilmiştir.

\section{ACKNOWLEDGEMENTS}

The current study was produced from the part of MSc Thesis of Deniz Altuntaş. The authors thank Muğla Sitkı Koçman University Research Fund (project no:15/038) for its financial support.

\section{Statement of Conflict of Interest}

Authors have declared no conflict of interest.

\section{Contribution of the Authors as Summary}

Authors declares the contribution of the authors is equal.

\section{REFERENCES}

Audet S 2010. Essai de découpage systématique du genre Scutiger (Basidiomycota): Albatrellopsis, Albatrellus, Polyporoletus, Scutiger et description de six nouveaux genres. Mycotaxon 111(1): 431-464.

Chen L, Cai Y, Zhou G, Shi X, Su J, Chen G, Lin K 2014. Rapid Sanger sequencing of the 16S rRNA gene for identification of some common pathogens. PloS one 9(2).

Doğan HH, Öztürk C, Kaşık G, Aktaş S 2005. A Checklist of Aphyllophorales of Turkey. Pakistan Journal of Botany 37(2): 459-485.

Felsenstein J 1985. Confidence limits on phylogenies: An approach using the bootstrap. Evolution 39:783- 
791.

Index fungorum: www.indexfungorum.org; accessed 25 July 2020.

Kimura M 1980. A simple method for estimating evolutionary rate of base substitutions through comparative studies of nucleotide sequences. Journal of Molecular Evoluon 16: 111-120.

Kirk PF, Cannon PF, Minter DW, Stalpers JA 2008. Dictionary of the fungi, 10th ed. CAB International. Wallingford, UK, 771p.

Kumar S, Stecher G, Li M, Knyaz C, Tamura K 2018. MEGA X: molecular evolutionary genetics analysis across computing platforms. Mol Biol Evol 35: 15471549.

Raja HA, Miller AN, Pearce CJ, Oberlies NH 2017. Fungal Identification Using Molecular Tools: A Primer for the Natural Products Research Community. J. Nat. Prod 80(3): 756-770.

Rogers SO, Bendich, AJ 1994. Extraction of total cellular DNA from plants, algae and fungi. In Plant molecular biology manual, Springer, Dordrecht, 183-190.

Sesli E, Denchev CM 2008. Checklists of the myxomycetes, larger ascomycetes, and larger basidiomycetes in Turkey. Mycotaxon 106: 65-67.

Stielow JB, Lévesque CA, Seifert KA, Meyer W, Irinyi
L, Smits D, Renfurm R, Verkley GJM, Groenewald M, Chaduli D, Lomascolo A, Welti S, LesageMeessen L, Favel A, Al-Hatmi AMS, Damm U, Yilmaz N, Houbraken J, Lombard L, Quaedvlieg W, Binder M, Vaas LAI, Vu1 D, Yurkov A, Begerow D, Roehl O, Guerreiro M, Fonseca A, Samerpitak K, van Diepeningen AD, Dolatabadi S, Moreno LF, Casaregola S, Mallet S, Jacques N, Roscini L, Egidi E, Bizet C, Garcia-Hermoso D, Martín MP, Deng S, Groenewald JZ, Boekhout T, de Beer ZW, Barnes I, Duong TA, Wingfield MJ, de Hoog GS, Crous PW, Lewis CT, Hambleton S, Moussa TAA, Al-Zahrani HS, Almaghrabi OA, Louis-Seize G, Assabgui R, McCormick W, Omer G, Dukik K, Cardinali G, Eberhardt U, de Vries M, Robert V 2015. One fungus, which genes? Development and assessment of universal primers for potential secondary fungal DNA barcodes. Persoonia: Molecular Phylogeny and Evolution of Fungi 35: 242-263.

Zheng HD, Liu PG 2008. Additions to our knowledge of the genus Albatrellus (Basidiomycota) in China. Fungal Diversity 32: 157-170.

Zheng HD, Liu PG, Wang XH, Yu FQ. 2004. Four new records in the genus Albatrellus (Aphyllophorales, Albatrellaceae) from China. Mycotaxon 90(2): 291299. 